Daniel CLINCI

Ovidius University of Constanţa

Constanţa, Romania

daniel_clinci@yahoo.com

\title{
PLASTIC MEMORIES OF THE ANTHROPOCENE
}

Recommended Citation: Clinci, Daniel. "Plastic Memories of the Anthropocene." Metacritic Journal for Comparative Studies and Theory 7.1 (2021):

https://doi.org/10.24193/mjcst.2021.11.05

\begin{abstract}
Plastic has become a ubiquitous material on planet Earth. I use Bennett's term, thing-power, to analyse various aspects of plastic's onto-materiality. Generally considered a single-use material, plastic is easily discarded, leaving the individualized, private space of capitalism, and becoming a nomad, in the terms of Deleuze and Guattari, thus travelling through a smooth space. Then, plastic enters a symbiotic relationship with all biotic and abiotic bodies, becoming endo-plastic. As a geological layer, it becomes a "vibrant" memory of the nexus between capitalism and humanism, revealing its full political potential. Plastic is a witness, by-product and determinant of the Anthropocene, and its memory tells the political and ideological geostory (Donna J. Haraway) of human exceptionalism. Becoming-plastic is one way of overcoming anthropocentrism: not just by advocating for "post-humanism," but by advocating for "posthum-ism," even if this means "embracing human extinction" (Patricia MacCormack).
\end{abstract}

Key words: Plastic, Posthumanism, Materialism, Vitalism, Anthropocene

While some of the recent materialist feminists claim that there is a shift from the poststructuralist interest in language to the contemporary one in matter (Alaimo, Material), there is, however, a line of thought that emphasized materiality and the question of "nature" at least since the 1970s, both in scientific writing (Lovelock) and in feminist theory (Griffin). Haraway's famous "cyborg" figure of the 1980 s is a result of these endeavours to deal with matter under the increasing prospect of ecological disaster in what we now refer to as "the Anthropocene." The threat of upcoming ecological crises has created an understanding of the fact that "matter matters" (Barad), which has allowed for different approaches to be formulated, from 
ecofeminisms to object-oriented and flat ontologies. Probably not surprisingly, the renewed interest in the works of Deleuze and Guattari offered the necessary tools to navigate the issue of materiality. In this paper, I will focus on the material memory, or memory of a material, as geostory (Haraway, Staying 40-1), onto-story (Bennett 4), or maybe geophilosophy (Deleuze, Guattari, What Is 102). I will explore plastic not only as a chrono-stratigraphic indicator of the geological unit of the Anthropocene, but also as an ecosophical marker of the nexus between humanism and capitalism, as a political and ideological marker of human exceptionalism, and as a material-discursive placeholder for the Anthropos in another name, the Plasticene.

In the article "Immanence: A Life," Deleuze posits the indefinite $a$ [un/une] as "always the index of a multiplicity: an event, a singularity, a life..." (Deleuze, "Immanence" 5), relinquishing the determination of individuality and the relationships of causality. Thus, a life as opposed to the definite the life defies a strict historical understanding, it is Nietzsche's will, sheer vitality. Bennett adds to this creative aspect the destructive one, a vitality expressed in the loss of contact with the life (social, cultural etc.), so as to describe "a life of metal" (Bennett 54) following a fragment on metallurgy from A Thousand Plateaus (Deleuze, Guattari, A Thousand 411). I argue that a nonorganic life similar to that of metal, or maybe even more complex and more far-reaching, is a life of plastic.

\section{A life of plastic}

A life of plastic is always in-between the moments of its social life, which is very limited. Covering a range of ubiquitous materials in contemporary societies, the first form of plastic was invented in 1907, and after Bakelite, many other forms appeared (PVC, Nylon, PET, etc.). Their stories include adventures like patents, court battles for rights, and huge corporations (Crawford, Quinn 8-17). The production of plastic increased exponentially after the Second World War, so that if by the end of the 1930 s 200,000 metric tons of Bakelite had been made (Crawford, Quinn 5), recent data show that global plastic production increased on the order of 20,000\% (Crawford, Quinn 39; Zalasiewicz, et al 444). Plastics are organic materials, that is, they are based on hydrocarbons (fossil carbon) in the form of polymer. Thus, they are a recent addition to the biogeochemical carbon cycle, but there is still no integrated approach to create a functional model of the plastic cycle as "the continuous and complex movement of 
plastic materials between different abiotic and biotic ecosystem compartments, including humans" (Bank, Hansson 7177).

As I have previously mentioned, the social life of plastic is very limited: beginning from synthetic textile fibres, bags and bottles, any other sort of packaging, and ending with the materials used in technology and infrastructure, plastic is shortlived. A life of plastic begins when it is inexorably discarded, this never-ending inbetween of plastic. Scientific texts propose that we look at the life cycle of plastic by using the already familiar vocabulary of the carbon cycle in trying to make sense of its presence: reservoirs, fluxes, sinks (Zhu 1; Qiu, et al 46), but most descriptions end in realizing the fact that plastic is literally everywhere, especially in the form of tiny particles - microplastic. Concerns regarding microplastic recently shifted from treating it as an exclusively marine or oceanic environmental issue due to its presence in terrestrial environments and even in living tissue. Since plastic is widely used to manufacture single-use items, it is also easily discarded and, under the influence of environmental factors such as ultraviolet radiation, it breaks down into microplastic particles which are floating in waters, are deposited on the ground (Li, et al 64; Zhou, et al 78) or are lifted and transported into the atmosphere (Zhang, et al 1). A recent attempt to create a model of the plastic cycle has shown, using the carbon cycle vocabulary, that plastic, generally speaking, does travel through fluxes (rivers) and settles in sinks (waterbeds). The resulting model is an extremely complicated figure which begins with consumer goods and ends up reinforcing the suspicion that plastic and microplastic particles permeate every place on Earth: the land, the atmosphere, freshwater environments, oceans, and biological tissue (Hoellein, Rochman 2).

Plastic is essentially junk. Consequently, it is a material memory of the model of consumption in contemporary capitalism (Bardini 9; Parikka 143-4). Since planned obsolescence is the main characteristic of production, plastic is readily disposable, not becoming junk, but already being junk: "Planned obsolescence, a nice way to say designed garbage" (Bardini 62). In a sense, capitalist consumption is the production of (micro)plastic waste. Marxist thinkers such as Wark and Foster used Marx's phrase, "the metabolic rift," to describe the carbon cycle and the environmental pressure of the Anthropocene (Wark xiv; Foster, Clark, York 75). In this context, "metabolism" refers to the cybernetic, self-governing processes of the Earth, like Lovelock's Gaia, but without the optimism. Understood in this manner, plastic is one aspect of the metabolic rift: as the ability to extract energy from fossil fuels ultimately allowed 
capitalism's global expansion, it also led to the current market ideology of designed obsolescence and, subsequently, to the production of junk. Plastic waste is the result of the disruption of Earth's metabolism by capitalism's need for infinite growth, much like the rise in atmospheric carbon (Foster, Clark, York 132), fuelled by the "consumer goods" from Hoellein and Rochman's model cited above, which rapidly end up as junk due to designed obsolescence. It is this junk that relates to Deleuze's immanence: a life of plastic begins when it loses its individuality, when it truly becomes "a material."

Much attention has been given to plastic as a potential stratigraphic marker of the Anthropocene. Deposits of plastic may already allow a clear delimitation of the Anthropocene as a new geological period (Zalasiewicz et al 4) by way of "technofossils." Plastic formations that have the potential of being technofossils, such as plastiglomerates and pyroplastics, have been reported. They can transport pathogens and release toxic chemicals, or plasticrusts, that can be ingested by living organisms, or anthropoquinas, plastic cemented in sedimentary rocks (De la Torre et al 6). Plastic is not only entering geological and stratigraphic records, but also archaeological ones. At an Iron Age site from Wales, archeologists began documenting late twentieth century and early twenty-first century life by finding and analysing plastic junk left behind by visitors, proving that this material has become the keeper of memories from a certain historical age (Mytum, Meek 198).

\section{A geology of plastic}

Material vitalism proposes that the question of agency is, first and foremost, not exclusively human; furthermore, it proposes that agency is only constructed, in the words of Nietzsche, as "an afterthought" of the event. In turn, the event is understood not as an interaction between agents, but as an intra-action, that is, the "mutual constitution of entangled agencies" (Barad 33, original emphasis). In another context, Alaimo's concept of trans-corporeality explicitly presents bodies within webs of "material interchanges" (Alaimo, Exposed 112) in the same way Deleuze and Guattari present the rhizome in opposition to hierarchical arborescent structures (Deleuze, Guattari, A Thousand 15). This same material vitalism prompts Bennett to consider the "thing-power" from a perspective that acknowledges the agency of assemblages, not that of individuals (Bennett 21). Indeed, it is not difficult to think of an agency of materials as assemblages or rhizomes, especially when we look at Deleuze and Guattari's plateau on "the geology of morals," where they describe a stratum as a 
material unity (Deleuze, Guattari, A Thousand 49), part of the "Mechanosphere" (Deleuze, Guattari, A Thousand 69), which already suggests a cybernetic interpretation. In turn, there is a material geology of plastic as a stratum in what Deleuze and Guattari refer to as a "plane of consistency":

The plane of consistency is the abolition of all metaphor; all that is consistent is Real. [...] The plane of consistency knows nothing of differences in level, orders of magnitude, or distances. It knows nothing of the difference between the artificial and the natural. It knows nothing of the distinction between forms and formed substances; these things exist only by means of and in relation to the strata. (Deleuze, Guattari, A Thousand 69-70, original emphasis)

Plastics may now exist in utter independence from social constrains, rules, or desires, but on a plane of consistency they form geological strata together with other assemblages. They are entangled not only with anthropic activities, but also with fossil fuels, capitalist consumption, sediments, air, waters, etc.

There are two ways to think about a geology or a geophilosophy of plastic from a material vitalist point of view. The first one seems almost apolitical since it is grounded in flat ontology and speaks of things as individual objects; the second one puts some Deleuze-Guattarian concepts into perspective and takes intra-action seriously, as co-constitutive agency, especially by eradicating the difference between the natural and the artificial. Since the Second World War, when plastic began to be used as a replacement for materials like wood, ivory, metal and so on, these assemblages intra-actively constituted the world. The social life of plastic is lived in the striated, fixed, and segmented spaces of the consumer society, of the State (Deleuze, Guattari, A Thousand 366), in individualized objects, and neatly given functionalities and presence. Plastic is discarded due to its relatively cheap, disposable, and single-use character, hence objects lose their individuality and become material. Leaving the striated space, plastic becomes nomad, travelling through the smooth space of waterways, riverbeds, winds, landfills, ocean floors, etc., in a deterritorialized flux of matter-energy, entering various other assemblages, biotic and abiotic. Paraphrasing Deleuze and Guattari, we may say that not everything is plastic, but plastic is everywhere; plastic is neither a thing nor an organism, but a body without organs (Deleuze, Guattari, A Thousand 411). A geology of plastic that perpetuates 
individuality together with the vitalist intensities of an object (Hawkins, "Plastic Materialities" 120), which is the first way of thinking, ultimately fails to account for nomadic plastic, for plastic as waste, as a body without organs, and as pure materiality, even though it manages to dissipate the distinction between the natural and the artificial. To acknowledge the fact that nomadic plastic enters and leaves assemblages means to recognize its thing-power and its political memory. Also, even from a posthuman materialist point of view this political memory and the geological agency is a result of the intra-action between plastic and the Anthropos.

Geological memory is not to be found exclusively in stratigraphy. On a plane of consistency, where the divide between nature and culture is erased, as it is the case with this geo-onto-story, assemblages carry geological memories with them. Alaimo, for instance, cites a long list of works that deal with the ways in which humans carry with them the geological memory of Earth. One example, taken from Carson, emphasizes that the original sea in which life developed runs through the circulatory system of every living being in the form of sodium, potassium, and calcium, and any skeleton is a remnant of the abundant calcium found in Cambrian oceans (Alaimo, Exposed 118). Such is the flux of matter-energy. Similarly, nomadic plastic travelling through the smooth space eventually reaches biotic bodies, interacting with living organisms in all environments (freshwater, seawater, coastal waters, soil, even polar regions). Recent studies have shown that plastic inhibits the growth, reproduction, and ecological interactions of essential organisms such as algae, bacteria, fungi, and plankton (Lu et al 95). Plastic particles have also been found in agricultural soil and, furthermore, in the organs and tissue of chicken (Lu et al 96). Finally, plastic has been found in stool samples of people all over the world (Schwabl et al 454), and in human placentas (Ragusa et al 3). Like the metals of the Cambrian seas which are found in every living tissue, plastic slowly permeates and deterritorializes bodies, proving that the intuition of Haraway's concept of “cyborg” from the 1980s as a naturecultural construct was extremely accurate. On the plane of consistency, which I tend to read in light of Haraway's natureculture or of the Earth as a body without organs, plastic is a geological stratum with rhizomatic offshoots. It deterritorializes ideas such as "nature," Lovelock's "Gaia," Serres' "Biogea," either as cybernetic, that is automatic and self-governing systems, or as a background for all political praxis, because its offshoots' intra-action with the Earth constructs a smooth space. At this point, it may seem that the perspective presented here leaves little room for a political 
understanding of plastic and it may also suggest a "flat ontology." However, this is not the case. Considering that plastic is a result of human capitalist activity and social modes of consumption and disposal, a political ecosophy of the material must include not only this geological aspect, but also something that most of the posthumanist and ecofeminist studies dedicated to material vitalism, junk, and plastic do not take into account: the fact that a life of plastic is not reduced to the life of plastic particles in "natural" or "human" environments, but integrated within the web of capitalism.

\section{An ecosophy of plastic}

In 1957, Roland Barthes published his Mythologies, which included a short entry on plastic. Barthes noticed that plastic is "less a thing than the trace of a movement," articulated in a two-fold manner as terrestrial material, a matter of the Earth, and as human object, enforcing the power of the human over "Nature" by its infinite transformation (Barthes 97). Since it can become anything, plastic democratized the obsession with imitation of the bourgeois capitalist, it replaced every other substance, even that of life (Barthes 98-99). Thus, Barthes managed to see that plastic is natureculture, that it erases the border between the terrestrial and the human, the natural and the artificial, the form and the formed, being a stratum on a plane of consistency. And yet Barthes emphasizes the fact that plastic is the pinnacle of the human's power over nature; if metals and other materials contain a memory of their origin, plastic embodies the memory of human society.

Since Barthes' 1957 book, in spite of the various naïve movements that promote a return to "nature," plastic has acted as an essential factor in the creation of consumer society. The democracy of consumption is grounded in the use of plastic as a ubiquitous material - from single-use items such as packaging to $3 \mathrm{D}$ printing processes which are no longer restricted to industrial applications and have become a household activity (Michael 30-1; Bensaude Vincent 23). Plastic is for everyone. Even water, which was regarded as a public good, readily available in most homes, is now bottled in plastic containers. Beginning from the 1990s, major corporations have used natural groundwater sources such as springs and aquifers to bottle water, taking advantage of the fact that these resources are poorly regulated in general (Hawkins, “The Politics" 185). This example offers a glimpse into another way to think about plastic's extraordinary rise as a consumer material. At a deeper level, it seems that Barthes, in his account of plastic, still used a binary, human versus nature dialectic. 
However, plastic is a product of capitalism's drive towards both profit and privatization. In Hawkins' bottled water example, using plastic containers and everything this entails such as portability, disposability or convenience privatizes the access to water, together with marketing strategies that present the dangers of tap water in opposition to the benefits of "pure" water and the medicalization of the act of hydration (Hawkins 190). Hawkins is right to assume that marketing water diminishes the materiality of the plastic bottle (Hawkins 191). Exclusively focusing on function and usability, capitalist marketing sells plastic without its materiality; therefore, a life of plastic, or its immanence, only begins when material vitalism is regained, when plastic is disposed of as waste or junk. Plastic democracy must deal with a huge amount of waste which must also become invisible, unnoticeable, inexistent. It does so by exporting trash to poorer regions of the planet.

A 2012 World Bank report on international waste management showed that rich, developed, heavily urbanized countries produced more than four times more trash than poor countries (World Bank 10). More than two decades before this report was published, in 1991, Lawrence Summers, Chief Economist of the World Bank, elaborated a scheme to "help correct an inefficient global imbalance in toxicity" (Nixon 1) by exporting first-world trash to third-world regions, thus easing the concerns of environmentalists of the Global North, and securing lost-lasting economic development for Europe and the United States. This practice enabled a form of "slow violence" against the African populations (Nixon 2) and a new take on historical colonial practices. Summers' argument was that Africa was inexcusably underpolluted; other neoliberal public policy makers defended the market logic of his proposal by stating that such a plan would "set in motion a dynamic process" which will lead to rising incomes in those poor countries (Johnson, Pecquet, Taylor 408). Now, this plan is well in effect. The current global plastic crisis has led to waste exports from overdeveloped regions such as the United States and other Westernized countries to underdeveloped ones such as sub-Saharan Africa, South-East Asia, and Eastern Europe. According to a study from 2018, higher income countries account for $70 \%$ of all plastic waste exports. Globally, it seems that only $9 \%$ of all plastic is actually recycled; the rest is dumped in landfills or into the environment. Almost half of all plastic waste was imported by China until 2018, when a ban was instituted, disrupting the global patterns of plastic waste trade (Brooks, Wang, Jambeck 1). A 2020 European Commission report on plastic waste export and import mentions that plastic 
ends up in the oceans, in landfills, or is burnt in open air. When China decided to stop importing Western plastic waste, it also revealed the underlying system of postcolonial oppression which is inherent in the process of transferring toxicity. Thus, countries such as Kenya, Thailand, Indonesia, and India have become the recipients of Western plastic (Lerner, "Waste Only"), stored in huge dumps where it is selected and purportedly recycled, a story which includes striking poverty, child labor, exposure to harmful chemicals, and a declining health (Lerner, "Africa's").

It is oftentimes ridiculous to speak of the Anthropos as a unified entity. The aforementioned aspects of the global plastic crisis describe the material's journey within the web of what Guattari called "Integrated World Capitalism (IWC)" (Guattari, The Three 31). For Guattari, Integrated World Capitalism is predicated on the three vectors of production, economy, and subjectification, all of which construct a semiotic system (Guattari, The Three 48). This semiotic assemblage should be approached with the transversal tools of an ecosophy: plastic stems from capitalist production under the profit motive, in an economy of planned obsolescence, constructing the capitalist subject-as-consumer. However, in turn, plastic makes possible this form of production-economy-subjectification. Of course, plastic then becomes an ecological concern, but at the same time it reinforces the old colonial practices of oppression and domination, constructing other subjects, namely the trans-species refugees of the Anthropocene, be they sea turtles or the children from a Nairobi landfill. This is the full political potential of plastic and its vibrant materiality, which exposes the nexus between humanism and capitalism. The subject of human exceptionalism is not a generic Anthropos, it is rather the capitalist subject-as-consumer of the overdeveloped world, produced by semiotic-material assemblages such as marketing and the media, resulted from the intra-action between plastic and bodies, and excluding numerous material lives. As there is a a life of plastic after its social function is fulfilled, there is a life of terrestrial and marine creatures whose lives matter in the web of Integrated World Capitalism only insofar they may be or become profitable. This immanence is a deep ecology, or even an ecosophy of posthuman vital materiality disclosed by plastic due to its transversal nature. Whatever is exterior to Integrated World Capitalism is the smooth space of ecosophy, that is, a space of nomadic bodies and materials. Plastic manages to cross into this space as (at least) a determinant of the Anthropocene, which itself is an ironic name, since it has to do less with biological human bodies, and more 
with the tradition of human exceptionalism deeply embedded in the practices of global capitalism.

\section{Anthropocene or Plasticene? An archeology of the future}

In a brief explanation regarding ecosophy, Guattari mentioned that the complexity of ecosophic objects is characterized by "chaosmic transversality" (Guattari, Chaosmosis 127). As we have already seen, plastic's vibrant materiality and life of immanence is truly transversal in that it contains the political memories of human exceptionalism and naturecultural intra-actions, while it deterritorializes bodies and environments. From an ecosophical and vital materialist perspective, plastic can become a placeholder for the Anthropos in the name given to this age, the Anthropocene. Considering that the human of humanism does not and cannot refer to the totality of biological human bodies enmeshed in intra-active processes, the "Plasticene" may become a likely candidate to denote this age, both from a stratigraphic-geological and from a geophilosophical and political point of view. The transversality of plastic, or in other words, its tentacularity (Haraway, Staying 31), preserves the ecosophical memory of anthropocentrism only as irony, honoring the tradition of Haraway's cyborg, namely that material-discursive feminist myth of "a creature of social reality as well as a creature of fiction" (Haraway, Manifestly 5). This manner of thinking about plastic seeks, first and foremost, to avoid two common misconceptions. The first one is Barthes' glorification of plastic as dominion over nature by humans, a perspective which is too limited in its use of these concepts as if they were opposites. The second one is the relatively general consensus found in most materialist approaches that plastic is a pollutant and must be dealt with in some way or another. Acknowledging the transversal immanence of plastic implies that we also acknowledge that it cannot be, strictly speaking, a foreign matter within the environment of nature. In turn, refusing to perpetuate the old distinctions between nature and culture, which is a feminist refusal found in Haraway's concept of the cyborg, means that we recognize that plastic is already embedded into the Earth as a naturecultural reminder of this age. In fact, even if the ecological issues regarding plastic would somehow be solved, plastic is still here to stay. Today, imagining a plastic-less planet is only an exercise in metaphysics. For instance, a 2019 report by the University of Newcastle, Australia, for the World Wildlife Fund brought together a few of the most relevant pieces of research in order to analyse how plastic is dissipated everywhere, from the water that we drink, 
to the air that we breathe, to the food that we eat (WWF 2019). Approaches like this are obviously useful in understanding and raising awareness about the ubiquity of plastic, but they are plagued by the same eco-anthropocentrism that fails to accept the fact that we are already cyborgs, both in the sense that living tissue and symbiotic microplastic form assemblages, and in the sense that the division between nature and culture is just another humanist fantasy that feeds the capitalist tendency of treating some assemblages and bodies as resources, while privileging others. In the Plasticene, the emphasis is not on the Anthropos, the generic human that actively works to modify the ecology and geology of the Earth, as it was the case with the Anthropocene (Crutzen 16), but on the material and political memory of stratum after stratum of plastic in the consistency of the Real.

It is this transversal and ecosophical presence of plastic that prompts a rethinking of geophilosophy. Haraway, in her attempt to create new stories of the Earth, new geo-stories, promoted the concept of compost to designate the rhizomatic or tentacular character of all beings, including human ones: "we are humus, not Homo, not Anthropos; we are compost, not posthuman" (Haraway, Staying 55). Plastic further complicates these stories, because it is a significant part of the compost heap, enmeshed and entangled in semiotic and living assemblages. If we are neither human, nor posthuman, then the only possibility to still be a part of the geostory of the Plasticene is to become-plastic. Becoming-plastic, not subjectivity or the subject of the geostory, but "molecular collectivities" (Deleuze, Guattari, A Thousand 275), is one way - probably the only one - to exit human exceptionalism, anthropocentrism, the oppressive networks of capitalism and colonialism, and to fully accept the transversality of plastic. If "we are humus" and, as we have seen, plastic is humus, then there is no way around becoming-plastic. The memories of metals like the calcium of exo- and endoskeletons and the iron of the blood may be archeological artefacts of the Cambrian seas, but the memory of plastic is the naturecultural artefact of a hypocritical, crumbling humanism. In the face of ecosophical drama and trans-species disasters, becoming-plastic means relinquishing individuality in favour of a molecular collectivity which is not even post-human, but post-humus. In other words, becomingplastic is not a posthumanism, it is a posthum-ism, if we consider MacCormack's radical idea of ending the Anthropocene, and thus ceasing the reproduction of humanism, by "cessation of human existence" (MacCormack 5). Becoming-plastic, which seems to already be an irreversible process, means nothing less than returning 
to the smooth space of the Earth, to the compost pile, in which bacteria that are capable of digesting plastic await as the new "architectural agents" (Gabrys 218) that will construct collective material politics, assemblages, and symbioses.

\section{References:}

Alaimo, Stacy, and Susan Hekman. Material Feminisms. Bloomington and Indianapolis: Indiana University Press, 2008.

---. Exposed. Environmental Politics and Pleasures in Posthuman Times. Minneapolis and London: University of Minnesota Press, 2016.

Bank, Michael S., Hansson, Sophia V. “The Plastic Cycle: A Novel and Holistic Paradigm for the Anthropocene." Environmental Science and Technology, 53, 2019. American Chemical Society: 7177-7179.

Barad, Karen. Meeting the Universe Halfway. Quantum Physics and the Entanglement of Matter and Meaning. Durham and London: Duke University Press, 2007.

Bardini, Thierry. Junkware. Minneapolis and London: University of Minnesota Press, 2011.

Barthes, Roland. Mythologies. New York: Farrar, Straus \& Giroux, 1972. Selected and translated from the French by Annette Lavers. [Mythologies. Editions du Seuil, 1957]

Bennet, Jane. Vibrant Matter. A Political Ecology of Things. Durham and London: Duke University Press, 2010.

Bensaude Vincent, Bernadette. "Plastics, materials and dreams of dematerialization.” Accumulation. The Material Politics of Plastic. Ed. Jennifer Gabrys, Gay Hawkins, and Mike Michael. London and New York: Routledge, 2013: 17-29.

Brooks, Amy L., Shunli Wang, and Jenna R. Lambeck, "The Chinese import ban and its impact on global plastic waste trade." Science Advances. American Association for the Advancement of Science, 2018: 4.

Crawford, Christopher Blair, Quinn, Brian. Microplastic Pollutants. Amsterdam: Elsevier, 2017.

Crutzen, P.J. "The 'Anthropocene'." Earth System Science in the Anthropocene. Ed. Eckart Ehlers, and Thomas Krafft. 2006: 13-8.

De-la-Torre, Gabriel Enrique, et al. "New plastic formations in the Anthropocene." Science of the Total Environment. 754 (2021): 1-8. 
Deleuze, Gilles, Félix, Guattari. A Thousand Plateaus. Capitalism and Schizophrenia. Minneapolis and London: Minnesota University Press, 1987. Translation and foreword by Brian Massumi [Mille Plateaux. Les Editions de Minuit, 1980]

---. What Is Philosophy? New York: Columbia University Press, 1994. Translated by Hugh Tomlison and Graham Burchell. [Qu'est-ce que la philosophie? Les Editions de Minuit, 1991].

Deleuze, Gilles. “Immanence. A Life...” Theory, Culture \& Society. Vol 14.2 (1997): 37. London, Thousand Oaks, and New Delhi: SAGE.

European Commission. Plastic waste shipments: new EU rules on importing and exporting plastic waste. December 22, 2020.

Foster, John Bellamy, Brett Clark, and Richard York. The Ecological Rift. Capitalism's War on the Earth. New York: Monthly Review Press, 2010.

Gabrys, Jennifer. "Plastic and the work of the biodegradable." Accumulation. The Material Politics of Plastic. Ed. Jennifer Gabrys, Gay Hawkins, Mike Michael. London and New York: Routledge, 2013: 208-25.

Griffin, Susan. Woman and Nature. The Roaring Inside Her. New York: Harper Collins, 1979.

Guattari, Félix. Chaosmosis. An ethico-aesthetic paradigm. Bloomington and Indianapolis: Indiana University Press, 1995. Translated by Paul Bains and Julian Pefanis. [Chaosmose. Editions Galilee, 1992].

---. The Three Ecologies. London and New Brunswick: The Athlone Press, 2000. Translated by Ian Pindar and Paul Sutton. [Trois ecologies. Editions Galilee, 1989].

Haraway, Donna J. Manifestly Haraway. Minneapolis and London: University of Minnesota Press, 2016.

---. Staying with the Trouble. Making Kin in the Chthulucene. Durham and London: Duke University Press, 2016.

Hawkins, Gay. "Plastic Materialities." Political Matter. Technoscience, Democracy, and Public Life. Ed. Bruce Braun and Sarah J. Whatmore. Minneapolis and London: Minnesota University Press, 2010: 119-37.

---. "The Politics of Bottled Water. Assembling bottled water as brand, waste and oil." Journal of Cultural Economy. Vol. 2. 1-2 (March/July 2009). London and New York: Routledge: 184-95. 
Hoellein, Timothy, and Chelsea M Rochman. "The global odyssey of plastic pollution.” Science. 368:6496, June 12, 2020. American Association for the Advancement of Science: 1184-1185.

Johnson, Jay, Gary Pecquet, and Leon Taylo,. "Potential Gains from Trade in Dirty Industries: Revisiting Lawrence Summers' Memo.” Cato Journal. Vol. 27.3 (Fall 2007): 397-410. Washington DC: Cato Institute.

Lerner, Sharon. “Africa’s Exploding Plastic Nightmare.” The Intercept. April 19, 2020.

---. "Waste Only." The Intercept. July 20, 2019.

Li, Wenfeng et al. "Microplastics in Agricultural Soils." Microplastics in Terrestrial Environments. Emerging Contaminants and Major Challenges. Defu He and Yongming Luo (eds.). Cham, Switzerland: Springer, 2020: 63-76.

Lovelock, James. Gaia. A new look at life on Earth. Oxford, UK: Oxford University Press, 2016 [1979].

$\mathrm{Lu}$, Liang et al. "Interaction between microplastics and microorganisms as well as gut microbiota: A consideration on environmental animal and human health.” Science of the Total Environment. 667 (2019): 94-100.

MacCormack, Patricia. The Ahuman Manifesto. Activism for the end of the Anthropocene. London and New York: Bloomsbury Academic, 2020.

Michael, Mike. "Process and plasticity. Printing, prototyping and the prospects of plastic.” Accumulation. The Material Politics of Plastic. Ed. Jennifer Gabrys, Gay Hawkins, and Mike Michael. London and New York: Routledge, 2013: 3046.

Mytum, Harold, Meek, James. "Experimental archeology and roundhouse excavated signatures: the investigation of two reconstructed Iron Age buildings at Castell Henllys, Wales.” Archeological and Anthropological Sciences. 12 (2020): 1-19.

Nixon, Rob. Slow Violence and the Environmentalism of the Poor. Cambridge, MA and London, UK: Harvard University Press, 2011.

Parikka, Jussi. A Geology of Media. Minneapolis and London: University of Minnesota Press, 2015.

Qiu, Rong et al. "Microplastics in Urban Environments: Sources, Pathways, and Distribution." Microplastics in Terrestrial Environments. Emerging Contaminants and Major Challenges. Ed. Defu He and Yongming Luo. Cham, Switzerland: Springer, 2020: 41-62. 
Ragusa, Antonio et al. "Plasticenta: first evidence of microplastics in human placenta." Environment International. 146 (2021): 1-7.

Schwabl, Philipp et al. "Detection of Various Microplastics in Human Stool." Annals of Internal Medicine. 171 (2019). 453-57. American College of Physicians.

Wark, McKenzie. Molecular Red. Theory for the Anthropocene. New York and London: Verso, 2016.

World Bank. What a Waste. A Global Review of Solid Waste Management. Washington, DC: World Bank, 2012.

World Wildlife Fund for Nature, Dalberg, The University of Newcastle. No Plastic in Nature: Assessing Plastic Ingestion from Nature to People. Gland, Switzerland: WWF, 2019.

Zalasiewicz, Jan, et al. "The geological cycle of plastic and their use as stratigraphic indicator of the Anthropocene." Anthropocene. 13 (2016): 4-17.

Zalasiewicz, Jan, Gabbott, Sarah, Waters, Colin N. "Plastic Waste: How Plastics Have Become Part of the Earth's Geological Cycle.” Waste. A Handbook for Management (second edition). Ed. Trevor M. Letcher and Daniel A. Vallero. London: Academic Press-Elsevier, 2019: 443-52.

Zhang, Yulan, et al. "Atmospheric microplastics: A review on current status and perspectives." Earth Science Reviews. 203, (2020): 1-15.

Zhou, Qian, et al. "The Distribution and Characteristics of Microplastics in Coastal Beaches and Mangrove Wetlands." Microplastics in Terrestrial Environments. Emerging Contaminants and Major Challenges. Ed. Defu He and Yongming Luo. Cham, Switzerland: Springer, 2020: 77-92

Zhu, Xia. "The plastic cycle - an unknown branch of the carbon cycle." Frontiers in Marine Science. 7: 609243, 2021. 